\title{
Biogenesis of Silver Nanoparticles and Its Multifunctional Anti-Corrosion and Anticancer Studies
}

\author{
Leena V. Hublikar ${ }^{1,2}$, Sharanabasava V. Ganachari ${ }^{3, * \mathbb{D}}$, Narasimha Raghavendra ${ }^{2}$, Nagaraj R. Banapurmath ${ }^{3} \mathbb{D}$, \\ Veerabhadragouda B. Patil 4 (D), T. M. Yunus Khan 5,6 (D) and Irfan Anjum Badruddin 5,6,*(D)
}

1 Department of Chemistry, KLE Technological University, BVB Campus, Vidyanagar, Hubbali 580031, Karnataka, India; shruthi.jamanoor@gmail.com

2 Department of Chemistry, KLE's P. C. Jabin Science College, Vidyanagar, Hubballi 580031, Karnataka, India; rcbhat3@gmail.com

3 Centre for Material Science, School of Mechanical Engineering, KLE Technological University, BVB Campus, Vidyanagar, Hubbalii 580031, Karnataka, India; nrbanapurmath@gmail.com

4 Institute of Energetic Materials, Faculty of Chemical Technology, University of Pardubice, 53210 Pardubice, Czech Republic; IamVeerabhadraa@gmail.com

5 Research Center for Advanced Materials Science (RCAMS), King Khalid University, P.O. Box 9004, Abha 61413, Saudi Arabia; yunus.tatagar@gmail.com

6 Mechanical Engineering Department, College of Engineering, King Khalid University, P.O. Box 394, Abha 61421, Saudi Arabia

* Correspondence: sharanu14@gmail.com (S.V.G.); magami.irfan@gmail.com (I.A.B.); Tel.: +91-836-2378295 (S.V.G.); +966-58307 5992 (I.A.B.)

check for updates

Citation: Hublikar, L.V.; Ganachari, S.V.; Raghavendra, N.; Banapurmath, N.R.; Patil, V.B.; Yunus Khan, T.M.; Badruddin, I.A. Biogenesis of Silver Nanoparticles and Its Multifunctional Anti-Corrosion and Anticancer Studies. Coatings 2021, 11, 1215. https://doi.org/10.3390/ coatings11101215

Academic Editor: Alina Vladescu

Received: 6 August 2021

Accepted: 27 September 2021

Published: 4 October 2021

Publisher's Note: MDPI stays neutral with regard to jurisdictional claims in published maps and institutional affiliations.

Copyright: (c) 2021 by the authors. Licensee MDPI, Basel, Switzerland. This article is an open access article distributed under the terms and conditions of the Creative Commons Attribution (CC BY) license (https:// creativecommons.org/licenses/by/ $4.0 /)$.

\begin{abstract}
In the present research, silver nanoparticles were synthesized using ground nutshell and characterized using UV-visible, FTIR and PXRD. The SEM and HR-TEM aided in confirming the nano size, surface morphology and phase purity of the AgNPs. The quantum chemical, electrochemical, and structural studies were carried out to understand electrochemical properties. In addition, biological study such as anti-cancerous activity was carried out, and IC-50 values $80.25 \mu \mathrm{g} / \mathrm{mL}$ for A549 lung cancer cell lines. The effective electrochemical anti-corrosion activities were also studied. The majority constituents of ground nutshell are flavonoids, in a small quantity of alkaloids and phenolic acids, which provide more stability to synthesize silver nanoparticles and avoid agglomeration. These functional moieties enhance the unique properties in the field, as in drug delivery systems, magnetic applications, and metallic, semi-conducting core-shell nanoparticles.
\end{abstract}

Keywords: ground nutshell extract; silver nanoparticles; high-resolution transmission electron microscopy; corrosion inhibition; Tafel plots; anti-cancerous activity

\section{Introduction}

Recently, nanoscience and technology have developed rapidly all over the world, largely by adopting the quality, advancement, and efficiency of nanoparticles [1,2]. The transition of metal nano-materials grabbed the attention of researchers due to massive applications in the field of environmental sciences, biomedical sciences, and electrochemical sciences [2-8]. The physical and chemical methods of synthesis of nanoparticles have limited advantages due to high toxicity [9-11]. These methods have a long process involvement and costly chemical usage [8,12]. The green synthesis of metal nanoparticles is environmentally safe, plant-mediated, biologically active, requires around one hour, and is a cost-effective synthesis process [13-17]. In this approach, the phytochemicals, the biologically active ingredients found in the extract of the plant, help in the reduction and stabilization of metal nanoparticles.

The AgNPs can be prepared using various biological materials, plants, microorganisms, and other dairy items. Recently reported works include the synthesis of Ag nanoparticles employing different plant compounds, including certain pelargonium graveolens, 
azardirachta indica and Tamarindus. It is used as an anti-inflammatory and injury curing agent and an analgesic agent for toothache, rhinitis, and cancer. The bioactive agents found in Schistosoma indicum contain olasonine, solamargine, indiosides, scopoletin, $\mathrm{N}$-(p-transcoumaroyl)-tyramine etc., which are helpful for a wide variety of medicinal applications.

The nanoscale has a wide area-to-volume ratio that allows applications to be produced in different areas, including drug delivery, microelectronics, antimicrobial materials, property, diagnosis, catalysis, bio-fertilizer, bio-mimicking, nano-sensing, antibacterial, antimicrobial and textile industrial applications [18-20]. One billionth of one meter is the nanometer scale. Nanoparticles themselves have their uniqueness in structures and properties. These show the possibilities of linkages between the bulk, atomic level and molecular levels. The ratio of smaller size and high surface volumes of nanomaterials is the reason behind the demand for these exceptional properties. Furthermore, the technologies adopted may be utilized in synthesis methods like the dry-method, the Wet-process, or computational ways of representing nanoscale particles [1,21-24].

Amongst these, the wet process involves living bioactive organisms for nano-synthesis. Plants are recognized in the field of nanotechnology because of their therapeutic activity and biological activities. The cytotoxicity studies of silver nanoparticles as antibacterial, antidiabetic and anti-cancerous activities facilitate more plant-based nanoparticles. Recent research has shown that different parts of plant species could successfully achieve silver nanoparticle synthesis by using fruit peels, plant barks, and nutshells. We treat it as waste and include various plants aspects, such as roots, flowers, seeds, barks, roots, and pulps. The phytochemicals present in bioactive plantsare usually secondary metabolites are key compositions for reducing metal salts to nano-size. The current study about silver nanoparticles has vital importance in nanoscale field, from ancient history and in more recent times in the industrial and medical fields [25-29].

Different diseases can create pathological changes in human cells. Cancer is one of them which also generates a cellular-metabolic change. The current therapies, like radiation and excess drug medication, have an adverse effect on the normal functioning of cells. Lung Cancer is also the biggest cause of mortality in cancer, although there is a decline in deaths (about 5\% in men and 4\% in women every year from 2013 on). These statistics are due to a decrease in smoking, the early detection of the disease, and effectively advanced treatment techniques. The metallic NPs (silver, gold and platinum) are generally tested in all human beings, then shown to be biocompatible with low-toxicity results. The silver nanoparticles synthesized chemically established promising areas in anticancer activity against A549, human lung cancer, in which silver nanoparticles synthesized like this attained a sort of intrinsic resistance towards platinating drugs and cisplatin. Thus, recent research on cancer medication is dedicated to detecting the novel transition of metal nanoparticles, preferably silver, because of their antipathogenic activities [30-32].

The wet chemical process, very helpful in the synthesis of large-scale nanoparticles, can be utilized in applications to reduce pollution by adsorbing poisonous gases from the atmosphere and acting as a green inhibitor for metal corrosions in acidic and basic media, and also in therapeutic applications, corrosion, and in cytotoxicity studies [33-35]. Many studies had shown the synthesis of $\mathrm{AgNP}_{\mathrm{S}}$ using $\mathrm{AgNO}_{3}$ (Silver nitrate) as a precursor. The secondary metabolites and phytocompounds are necessary for the reduction of $\mathrm{AgNO}_{3}$, and behave as a capping agent. The ggroundnut, commonly called a peanut, grows under the ground. Thus, the name is groundnut. This is one of the less explored traditional, widely used plants that have significant commercial applications $[14,36]$.

It is one of the Kharif crops grown during the June to September period, and it is neither a fruit nor a vegetable. It is considered a nut and a protein group in the food pyramid. A major part of the groundnut shell is used to feed animals and remains a waste material for bio-fertilizer [37]. There is no specific report in the literature on synthesizing silver nanoparticles using groundnut shell extract and as an anticancer and anti-corrosion species. Hence, we selected groundnut shells and the green species in ground nutshell 
extract in the present work using Soxhlet extraction techniques. The newly synthesized AgNPs were validated employing UV-Visible, FTIR, XRD, SEM and TEM studies. The corrosion studies were performed by using AAS, TAFEL and impedance spectroscopy techniques. Further, Chemical quantum studies are also employed to support AAS and electrochemical results. Similarly, anticancer activity on MTT cell lines A435 with $\mathrm{IC}_{50}$ value $80.25 \mu \mathrm{g} / \mathrm{mL}$ have shown promising results for this investigation.

\section{Materials and Methods}

The fresh groundnuts are collected in August from the most fertile soil of Dharwad district, India. Groundnut shells were cleaned with purified water to eliminate dirt and mud contaminations which can toxicate the extract. Shells were dried in sunlight, blended into powder, stored in plastic bottles, and kept in the refrigerator until used. Soxhlet extraction is only needed if the target compound has minimal solubility, and the impurity is insoluble in the solvent. If the target compound has a high solvent solubility, a quick filtration isolates the compound from the insoluble material. Hence in the present investigation, Soxhlet extraction is preferred. The powder $(50 \mathrm{~g})$ is kept in the Soxhlet apparatus (Borosil, Gurgaon, India) and solvent, benzene, for the extraction. The round-bottomed flask is placed at the bottom of the thimble by adding 2-3 boiling chips (that avoids bumping of the solution). Extraction was carried out at $100{ }^{\circ} \mathrm{C}$ for a minimum of 18 to 20 cycles. After that, the phytocompounds from the ground nutshell get collected in the R. B. flask. During each cycle, the non-volatile compound of the sample gets concentrated in the extraction. The solution from R. B. flask is the ground nutshell extract (GNS extract) that acts as the reducing/capping agent. The solution is filtered, and the residue was collected into a separate beaker. The extract is light-brown in colour, as in Figure 1.

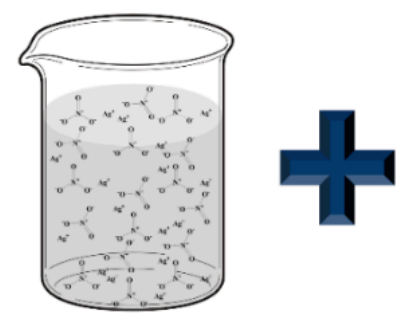

Silver nitrate solution

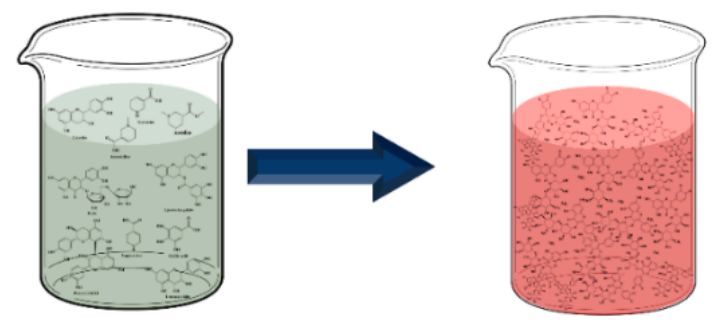

AgNPs colloidal solution

Figure 1. Green synthesis AgNPs.

\subsection{Synthesis of AgNPS}

About $200 \mathrm{~mL}$ of $0.01 \mathrm{~N} \mathrm{AgNO}_{3}$ solution was added to the extract. The ground nutshell extract is reduced now to the $\mathrm{AgNO}_{3}$ (i.e., $\mathrm{Ag}^{+}$to $\mathrm{Ag}^{0}$ ) to its nanoscale by mainly three steps: nucleation, accumulation, and stabilization. The extract solution changes from reddish-brown to dark brown color that indicates the formation of $\mathrm{AgNO}_{3}$. One to two drops of freshly prepared $0.1 \mathrm{~N} \mathrm{NaOH}$ solution were added to maintain $\mathrm{pH}$ of 7-9 to form the AgNPs with higher yield and smaller size. After two to three days, the water in the container evaporates, and only AgNPs are placed on a magnetic stirrer (Remi, Thane, India) for heating. Thus, the AgNPs are obtained in the form of powder. The powdered AgNPs were weighed on balance to determine their concentrations per gm. About $5 \mathrm{mg}$ of AgNPs were obtained per $50 \mathrm{gm}$ of ground nutshell material. To understand the ease of structure, morphology and properties of synthesized silver nanoparticles were characterized employing UV-Visible, FTIR, SEM and TEM methods. Further, those are interconnected with applications in corrosion studies [38,39] and anticancer activities [30].

\subsection{Characterization Methods}

Prime techniques incorporated to characterize are as follows, AgNPs were screened with UV-Visible spectroscopy on LABMAN LMSP-UV1200 (Lamaman, Chennai, India) with a wavelength accuracy of $+0.5 \mathrm{~nm}$. A Fourier-transform infrared spectroscopy (FT-IR) 
study was performed to confirm the formation of green silver nanoparticles in the range of $4500-400 \mathrm{~cm}^{-1}$ by instrumentation at the Sophisticated Analytical Instrumentation Facilities (SAIF) Centre, Karnatak University, Dharwad (KUD) India by using NICOLET 6700, (Thermo Scientific, Pune, India) instrument. X-ray Powder Diffraction (X-RD) of model Xpert MPD, Philips, Amsterdam, The Netherlands was used to analyze the structure of the newly synthesized AgNPs. The XRD patterns were recorded on X-ray diffractometer at the range of $2 \theta$ from $3^{\circ}$ to $136^{\circ}$ using $\mathrm{Cu}$ target $\mathrm{X}$-ray tube, $\mathrm{Cu} \mathrm{K} \alpha(\lambda=1.5406 \mathrm{~A})$ radiation with a tracking voltage of $40 \mathrm{kV}$. Scanning Electron Microscopy (SEM-EDX, (JEOL, Tokyo, Japan) was carried out to learn the external morphology of AgNPs. A scanning electron microscope (JEOL, Tokyo, Japan) was also used to study morphological characteristics of synthesized AgNPs with an accelerating voltage with LaB6 filament $2 \mathrm{~nm} 30 \mathrm{kV}$ with $\mathrm{W}$ filament $3.5 \mathrm{~nm}$ at $30 \mathrm{kV}$ by emission current of 0 to $200 \mu \mathrm{A}$ and accelerating voltage: 0.2 to $30 \mathrm{kV}$. The size, shape, and morphology of synthesized AgNPs, were confirmed using HR-TEM(Thermofisher, New York, NY, USA), performed in TEM Lab, Centre for Nano and Soft Matter Sciences (CeNS), Bengaluru. Atomic absorption spectroscopic analysis (AAS) was performed using the Atomic Absorption spectrometer with graphite furnace and autosampler ${ }^{222} \mathrm{Rn}$ and ${ }^{220} \mathrm{Rn}$ mitigation systems gamma dosimeter (Thermofisher, New York, NY, USA), survey meter and GPS TLDs, Pinhole dosimeter (from Electronics and Engineering Pvt Ltd., Dadra, India), performed in DTPS and DRPS USIC Centre Mangalore University, India.

\section{Results and Discussion}

\subsection{Phytochemical Screening}

The qualitative and quantitative investigation of phytochemicals identify the molecules of the samples, and from this analysis, results obtained are shown in Table 1. Recent studies showed that GNS-extract contains a major quantity of flavonoids (catechin, epicatechin gallate, leucocyanidin, procyanidin B1 and rutin), some alkaloids (arecoline, arecaidine, guvacine, iso-guvacine) and traces of phenolic acids (gallic acid). Flavan-3-ol (catechin)is a secondary metabolite and natural polyphenol form and anti-oxidant. Another flavan-3-ol, flavonoid, epicatechin gallate is present in green tea, buckwheat and in grapes. The additional class of natural products, a derivative of flavonoid leucoanthocyanidins. Molecules of catechins and epicatechins produce extracellular substances. The procyanidins became part of the flavonoid proanthocyanidin family. The quercetin-3-O-rutinoside and sophorin together rutoside or Rutin. Alkaloids, like Arecaidine, Arecoline \& Guvacine are acidbased alkaloids found in the areca nut and fruit of the areca palm. The iso-guvacine is a dimer of guvacine. Gallic acid is known of total phenolic identified in the extract and trihydroxybenzoic acid, found in tea leaves, oak bark, and gallnuts.

Phytochemicals like, alkaloids, terpenoids, carbohydrates and other active biomolecules reduce metal cations to their elemental metals. This transformation from positive to zero oxidation state enhances the size distribution of metal nanoparticles through indorsing new nuclei for faster reaction progress, and also by forming a monolayer (capping) on the nano-surface prevents the clustering of the nanoparticles. These surface-active molecules functionalize the nanoparticles towards biological activity. The enhanced anti-cancerous activity can be enlightened due to the phytochemicals attached at the surface $[40,41]$. The biomolecules of the ground nutshell extracted act here as both reductant as well as capping agents. The capped nature, the surface of nanomaterials becomes active therapeutic agents, reduces the level of toxicity, and prevents the accumulation of particles [42,43]. 
Table 1. Phytochemical results.

\begin{tabular}{|c|c|c|c|}
\hline S.No. & Test & Observation & Inference \\
\hline I (a) & \multicolumn{3}{|c|}{ Qualitative Analysis: Test for Alkaloids } \\
\hline 1. & $\begin{array}{c}\text { Mayer' s test: } \\
\text { GNS extract + Mayer's reagent }\end{array}$ & white creamy precipitate & Presence of Alkaloids are confirmed \\
\hline 2. & $\begin{array}{c}\text { Wagner's test: } \\
\text { GNS extract + Wagner's reagent }\end{array}$ & reddish-Brown precipitate & Presence of Alkaloids are confirmed \\
\hline $\mathrm{I}(\mathrm{b})$ & \multicolumn{3}{|c|}{ Qualitative Analysis: Test for Amino acids } \\
\hline 1. & $\begin{array}{c}\text { Ninhydrin test: } \\
\text { GNS extract }+ \text { Two drops of ninhydrin solution }\end{array}$ & purple colour & $\begin{array}{l}\text { Presence of Amino acids are } \\
\text { confirmed }\end{array}$ \\
\hline $\mathrm{I}(\mathrm{c})$ & \multicolumn{3}{|c|}{ Qualitative Analysis: Test for Carbohydrates } \\
\hline 1. & $\begin{array}{c}\text { Molish's test: } \\
\text { GNS extract }+\alpha \text {-naphthol in alcohol, two drops }+ \\
\text { concentrated sulfuric acid }\end{array}$ & No violet ring & presence of carbohydrates. \\
\hline 2. & $\begin{array}{l}\text { Benedict's s test: GNS extract + Benedicts reagent } \\
\text { heated on a boiling water bath }\end{array}$ & coloured precipitate & presence of sugar \\
\hline $\mathrm{I}(\mathrm{d})$ & \multicolumn{3}{|c|}{ Qualitative Analysis: Saponification test } \\
\hline 1 & $\begin{array}{l}\text { GNS extract + Alc. potassium hydroxide + drop of } \\
\text { phenolphthalein heated on a water bath for } 2 \mathrm{~h}\end{array}$ & No Formation of soap & Absence of oils and fats \\
\hline $\mathrm{I}(\mathrm{e})$ & \multicolumn{3}{|c|}{ Qualitative Analysis: Test for Glycosides } \\
\hline 1. & $\begin{array}{c}\text { Legal's test } \\
\text { GNS extract }+ \text { Pyridine }+ \text { sodium nitroprusside } \\
\text { solution }+10 \% \mathrm{NaOH}\end{array}$ & - & - \\
\hline
\end{tabular}

I (f) Qualitative Analysis: Phenolic compounds and Tannins

1. GNS extract $+5 \mathrm{~mL}$ of distilled water $+5 \%$ ferric $\quad$ No dark green colour $\quad$ Absence of phenolic compound chloride solution Lead acetate test

2. GNS extract $+5 \mathrm{~mL}$ of distilled water $+10 \%$ lead No bulky white precipitate Absence of phenolic compounds acetate solution

3. Alkaline reagent test GNS extract $+10 \%$ ammonium hydroxide solution

Magnesium and Hydrochloric acid reduction

4. GNS extract $+5 \mathrm{~mL}$ of alcohol+ few fragments of magnesium ribbon+ concentrated hydrochloric acid Qualitative Analysis: Test for phytosterols Libermann-Burchard's test
1.
GNS extract $+2 \mathrm{~mL}$ acetic anhydride +2 drops of concentrated sulphuric acid Qualitative Analysis: Test for Proteins

\begin{tabular}{|c|c|c|c|}
\hline 1. & $\begin{array}{c}\text { Millon's test } \\
\text { GNS extract }+2 \mathrm{~mL} \text { of Millon's reagent }\end{array}$ & No white precipitate & Absence of proteins \\
\hline I (i) & \multicolumn{3}{|c|}{ Qualitative Analysis: Test for Saponins } \\
\hline 1. & $\begin{array}{l}10 \mathrm{~mL} \text { of GNS extract diluted with distilled water } \\
\text { and made up to } 20 \mathrm{~mL}\end{array}$ & No layer of foam & Absence of saponins \\
\hline$I(j)$ & \multicolumn{3}{|c|}{ Qualitative Analysis: Test for gum and Mucilages } \\
\hline 1. & $\begin{array}{c}10 \mathrm{~mL} \text { of GNS extract }+2 \mathrm{~mL} \text { of absolute alcohol } \\
\text { stirs well }\end{array}$ & No cloudy precipitate & Absence of Gums and Mucilage \\
\hline
\end{tabular}


The core-shell nanoparticles (CSNPs) are described as containing the inner material, known as the core, and the outer layer material, which is known as the shell. They consist of a wide variety of combinations of close contact and inorganic/inorganic. The selection of core-shell material of the nanoparticle shell usually is highly dependent on the final application and use. The CSNPs are highly functional compounds with altered properties. Frequently, the properties of either core or shell materials can be very different. The properties can be changed by changing either the composition of the components or the ratio of the center to the shell. Due to the shell material covering, the core particles properties, such as the reduction of reactivity or thermal stability, can be improved to improve the overall stability of the particle and the dispersibility of the core particle. Finally, the particles exhibit distinctive characteristics of the various materials used together. The CSNPs are becoming more attractive as these nanoparticles have emerged at the boundary between chemical materials and many other fields, such as computing, biomedical, medicinal, optical, and catalysis.

An organic biological moiety encapsulates a cluster of a few nanoparticles to create a healthy core-shell morphology, as shown in Figure 2. The biological moiety consists of a significant part of flavonoids and alkaloids from groundnut extract. These act as reducing and stabilizing agents to create stable metal nanoparticles and contribute its tremendous surface interaction towards anticorrosion anticancer studies.

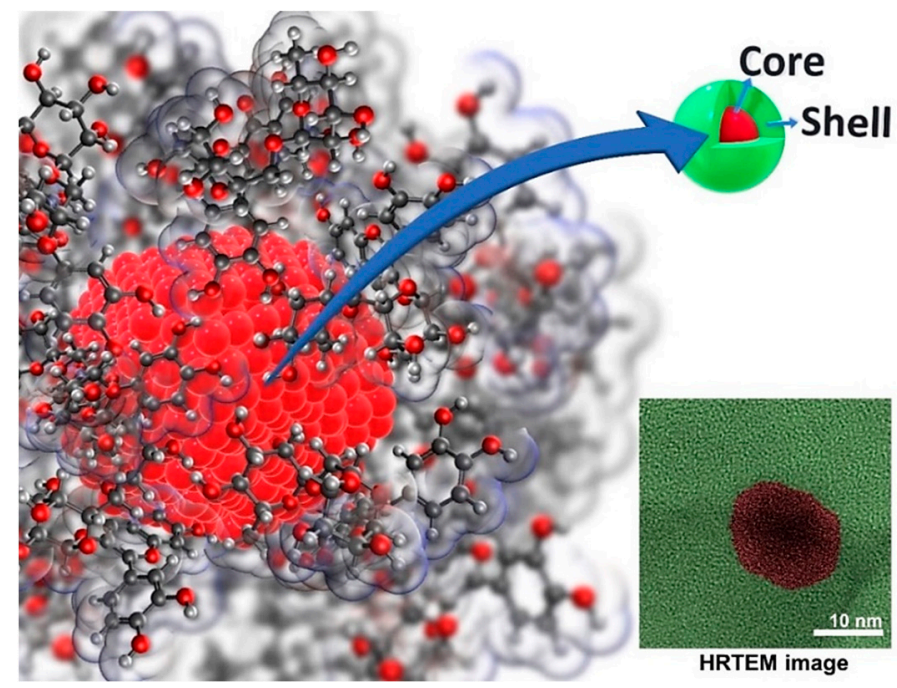

Figure 2. Schematic representation of the core-shell structure of functionalized silver nanoparticles.

\subsection{Computational-Chemical Approach}

The recent reports from computational chemists realized the understanding of the molecular structure and their reactivities. The quantum chemical parameters, electron movement in HOMO and LUMO, orbitals together are responsible for chemical reactivity. The HOMO is the maximum orbital energy and is filled by electrons. Hence, electrons can be removed from it. LUMO is the minimum orbital energy, which would be empty. Theoretical chemical calculations of HOMO-LUMO were considered in the present study to explain the different periodic properties of molecules involved. The $\mathrm{E}_{\mathrm{HOMO}}$ and $\mathrm{E}_{\mathrm{LUMO}}$ values were gained from the advanced Argus Lab software (4.0.1). The chemical names, molecular structure, HOMO-LUMO and other quantum chemical values are tabulated in Table 2. 
Table 2. Values of HOMO-LUMO for chemical constituents.

\begin{tabular}{|c|c|c|}
\hline Chemical Name & Molecular Formula & Structural Formula \\
\hline Arecoline: & $\mathrm{C}_{8} \mathrm{H}_{13} \mathrm{NO}_{2}$ & \\
\hline Arecaidine: & $\mathrm{C}_{7} \mathrm{H}_{11} \mathrm{NO}_{2}$ & \\
\hline Guvacine: & $\mathrm{C}_{6} \mathrm{H}_{9} \mathrm{NO}_{2}$ & \\
\hline Iso-Guvacine: & $\mathrm{C}_{6} \mathrm{H}_{9} \mathrm{NO}_{2}$ & \\
\hline Catechin: & $\mathrm{C}_{15} \mathrm{H}_{14} \mathrm{O}_{6}$ & \\
\hline Epicatechin gallate: & $\mathrm{C}_{22} \mathrm{H}_{18} \mathrm{O}_{10}$ & \\
\hline Leucocyanidin & $\mathrm{C}_{15} \mathrm{H}_{14} \mathrm{O}_{7}$ & \\
\hline Gallic acid: & $\mathrm{C}_{7} \mathrm{H}_{6} \mathrm{O}_{5}$ & \\
\hline Procyanidin B1: & $\mathrm{C}_{30} \mathrm{H}_{26} \mathrm{O}_{12}$ & \\
\hline Rutin: & $\mathrm{C}_{27} \mathrm{H}_{30} \mathrm{O}_{16}$ & \\
\hline
\end{tabular}

I (Ionization potential) and E (electron affinity) The Equations (1) and (2) are determined as,

$$
\begin{aligned}
& \mathrm{I}=-\mathrm{E}_{\text {HOMO }} \\
& \mathrm{E}=-\mathrm{E}_{\mathrm{LUMO}}
\end{aligned}
$$

$\chi$ (Electronegativity) and $\eta$ (Chemical hardness) can be related as respectively follows in $3 \& 4$,

$$
\begin{aligned}
& \chi=I+E / 2 \\
& \eta=I-E / 2
\end{aligned}
$$

Chemical softness or Electron polarizability $(\sigma)$ and Chemical potential $(\mu)$ are formulated according to the relations $5 \& 6$

$$
\sigma=\mathrm{I}
$$




$$
\mu=-\chi
$$

Electrophilicity index $(\omega)$ can be equated as in 7 ,

$$
\omega=\mu^{2} / 2 \eta
$$

Above data I (ionization potential), $\mathrm{E}$ (electron affinity), $\eta$ (chemical hardness), $\chi$ (Electronegativity), Electron polarizability $(\sigma)$, chemical potential $(\mu)$ and band gap were calculated and tabulated in the Table 3 . This study provides a wide idea for understanding structural features. The molecular structures of ten natural components contain double bonds, $\mathrm{N}$ and $\mathrm{O}$ atoms in their structures.

\begin{tabular}{|c|c|c|c|c|c|c|c|c|c|c|}
\hline $\begin{array}{l}\text { Name of } \\
\text { Medicinal } \\
\text { Compound }\end{array}$ & $\mathrm{E}_{\text {HOMO }}(\mathrm{eV})$ & $E_{\text {LUMO }}(\mathrm{eV})$ & $\begin{array}{c}\text { Energy } \\
\text { Gap }(\mathrm{eV})\end{array}$ & $\mathbf{I}$ & E & $\eta$ & $x$ & $\Sigma$ & $\mu$ & $\omega$ \\
\hline Arecoline & -0.617735 & -0.306484 & 0.311251 & 0.6177 & 0.3064 & 0.155 & 0.462 & 6.425 & -0.462 & 0.688 \\
\hline Arecaidine & -0.613442 & -0.327682 & 0.285762 & 0.6134 & 0.3276 & 0.142 & 0.470 & 6.998 & -0.470 & 0.777 \\
\hline Guvacine & -0.664881 & -0.366108 & 0.298773 & 0.6648 & 0.3666 & 0.149 & 0.515 & 6.694 & -0.515 & 0.890 \\
\hline Iso-Guvacine & -0.652635 & -0.353851 & 0.298784 & 0.6526 & 0.3538 & 0.1494 & 0.503 & 6.693 & -0.503 & 0.846 \\
\hline Catechin & -0.332934 & -0.117081 & 0.215853 & 0.3332 & 0.1170 & 0.107 & 0.225 & 9.265 & -0.225 & 0.236 \\
\hline $\begin{array}{l}\text { Epicatechin } \\
\text { gallate }\end{array}$ & -0.257874 & -0.241204 & 001667 & 0.2578 & 0.2412 & 0.0083 & 0.249 & 119.976 & -0.249 & 3.735 \\
\hline Leucocyanidin & -0.359516 & -0.067597 & 0.291919 & 0.3595 & 0.067 & 0.145 & 0.213 & 6.851 & -0.213 & 0.156 \\
\hline Gallic acid: & -0.335691 & -0.074460 & 0.261231 & 0.3356 & 0.744 & 0.204 & 0.540 & -4.891 & -0.540 & 0.7147 \\
\hline $\begin{array}{c}\text { Procyanidin } \\
\text { B1: }\end{array}$ & -0.244559 & -0.213046 & 0.031513 & 0.2445 & 0.213 & 0.015 & 0.228 & 63.467 & -0.228 & 1.73 \\
\hline Rutin: & -0.245843 & -0.236324 & 0.009519 & 0.2458 & 0.236 & 0.004 & 0.241 & 210.106 & -0.241 & 7.26 \\
\hline
\end{tabular}

Table 3. Quantum chemical parameters (by using PM3) method.

The above investigations show natural constituents of the plants exhibit high values $\mathrm{E}_{\mathrm{HOMO}}$ in $\mathrm{eV}$ for alkaloids compared to flavonoids. These medicinal compounds, acecainide $(\mathrm{HOMO}=-0.617735)$, arecoline $(\mathrm{HOMO}=-0.613442)$, guvacine $(\mathrm{HOMO}=-0.664881)$ and iso-uvagcine $(\mathrm{HOMO}=-0.652635)$ with high $\mathrm{E}_{\mathrm{HOMO}}$ values are electron rich species, which donates electrons to species having empty molecular orbital of low energy and which can take an electron from the electron-rich organic compounds. The other related properties are discussed as follows,

- $\quad$ Ionization potential (I), values of HOMO are higher and explain the stability of organic compounds. Lower is the I value, higher is the reactivity of organic moieties. Therefore reactivity, based on I values, is related as Procyanidin B1 > Rutin $>$ Epicatechi gallate $>$ Catechin $>$ Gallic acid $>$ Leucocyanidin $>$ Arecaidine $>$ Arecoline $>$ Iso-Guvacine $>$ Guvacine.

- The increase in the energy gap value, decrease in the reactivity of organic compound on the surface. The trend is in the order of, Rutin $>$ Epicatechi gallate $>$ Procyanidin B1 $>$ Catechin $>$ Gallic acid $>$ Leucocyanidin $>$ Arecaidine $>$ Guvacine $>$ Iso-Guvacine $>$ Arecoline.

- The electrophilic or nucleophilic nature of natural components can be predicted by Electrophilicity $(\omega)$ values. Higher the $\omega$ values, the stronger the electrophile and the lower the $\omega$ values, the stronger the nucleophile. Thus, Rutin is a strong electrophile, and Procyanidin B1 is a strong nucleophile.

- The softness and hardness are dynamic parameters to measure the reactivity and stabilities of the natural components. The greater the $\eta$, values the greater is the softness of the compound. Thus, Rutin is the less soft compound.

\subsection{Characterization of GNS-AgNPS}

The groundnut shell extract and silver nitrate solution mixture turning from light yellow to brown after the incubation time of half an hour indicates that $\mathrm{Ag}^{+}$reduces to 
$\mathrm{Ag}^{0}$, and structural identification of metal nano-particles are confirmed by using the UVVisible technique. In Figure 3, the surface plasmon resonance of electrons obtained for GNS-AgNPs is $378 \mathrm{~nm}$, which explains the formation of silver nanoparticles. Further, the increase in the intensity of SPR peak which increases with time also confirms the formation of GNS-AgNPs.

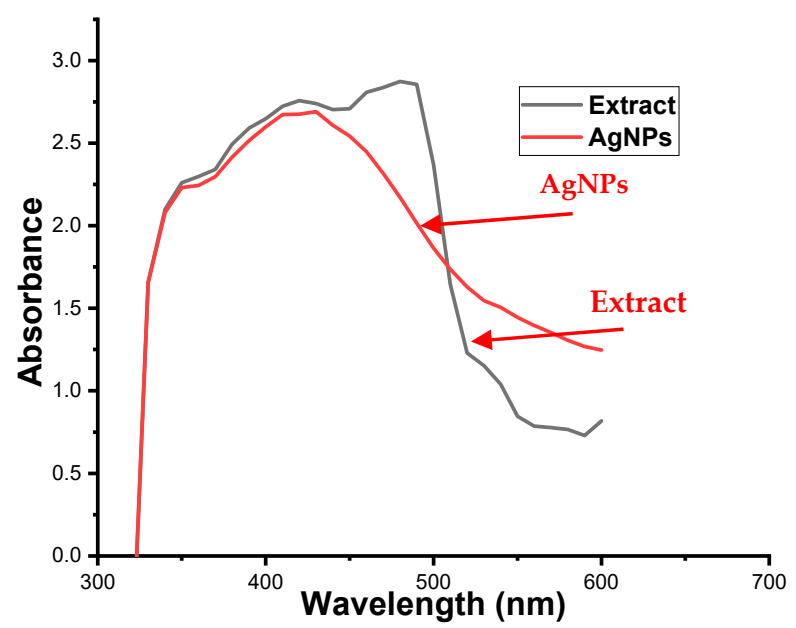

Figure 3. UV-Visible spectra of extract and AgNPs.

The FTIR spectroscopic method is an essential tool to spot the new compound and recognize the secondary metabolites of the groundnut shell extract, which are acting as reducing and stabilizing agents for GNS-AgNPs. The plots obtained by transmittance with a wavelength of FTIR spectra show a clear difference in their results. The pure extract and of AgNPs bands as in Figure 4 about 3500 and $2500 \mathrm{~cm}^{-1}$. The band shows the occurrence of $\mathrm{O}-\mathrm{H}$ polyphenol stretching found in the extract. The $1624 \mathrm{~cm}^{-1}$ band refers to a group of carbonyl strip amides in the bark extract containing proteins. The 1628.56 is of $\mathrm{C}=\mathrm{O}$, and $1384.05 \mathrm{~cm}^{-1}$ is of $\mathrm{C}-\mathrm{O}$ bands were stretching and bending frequencies respectively. The above bands demonstrate the identity of flavonoids and terpenoids from ground nutshell compounds [44,45].

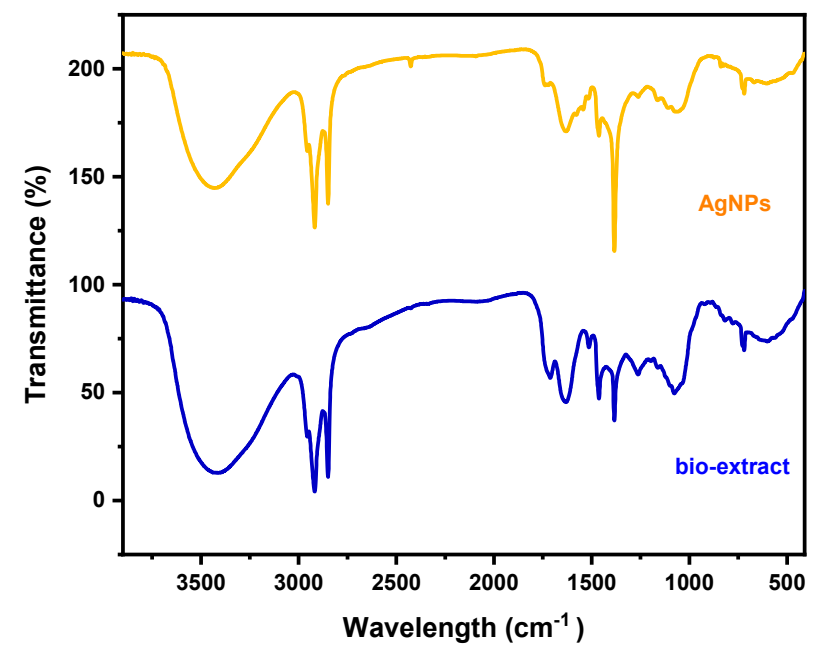

Figure 4. FT-IR spectrum of AgNPs and bio extract.

The peak at $3431.33 \mathrm{~cm}^{-1}$ is due to the $\mathrm{N}-\mathrm{H}$ extending the vibration of plant organic compounds absorbed into the body to silver NPs. In the same way, relative to pure ground nutshell extract, the IR bands are moved from 2960.24 to $2955.03,1632.24$ to 1628.52 and 1514.38 to $1577.43 \mathrm{~cm}^{-1}$. These changes demonstrate that types of proteins and 
metabolites, terpenoids, flavonoids and polyphenols are implicated in the reduction and bio-encapsulation of AgNPs. The peak at $1620.88 \mathrm{~cm}^{-1}$, aromatic $\mathrm{C}=\mathrm{C}$ in carboxyl group, which also quercetin peaks (12).

The X-ray diffractograms shown in Figure 5 identifies the phase purity and crystal structure of a sample- the silver nanoparticles, of the GNSE-AgNPs identified by diffraction peaks of XRD. The XRD pattern of GNSE-AgNPs obtained here is shown prominent peaks observed at (111), (200) and (220) a with agreeing $2 \theta$ values as $38.28^{\circ}, 44^{\circ}, 64.36^{\circ}$ and $77.12^{\circ}$. It indicates the crystalline presence and is accredited to the fcc structure of GNSE-AgNPs (JCPDS 89-3722). The calculated crystallite size of GNSE-AgNPs is to be $12-15 \mathrm{~nm}$. However, grain size of GNSE-AgNPs is marked by the peaks at (111) using the Scherer formula. The XRD studies also reflect a synthesis of GNSE-AgNPs by the reduction of GNSE-AgNPs.

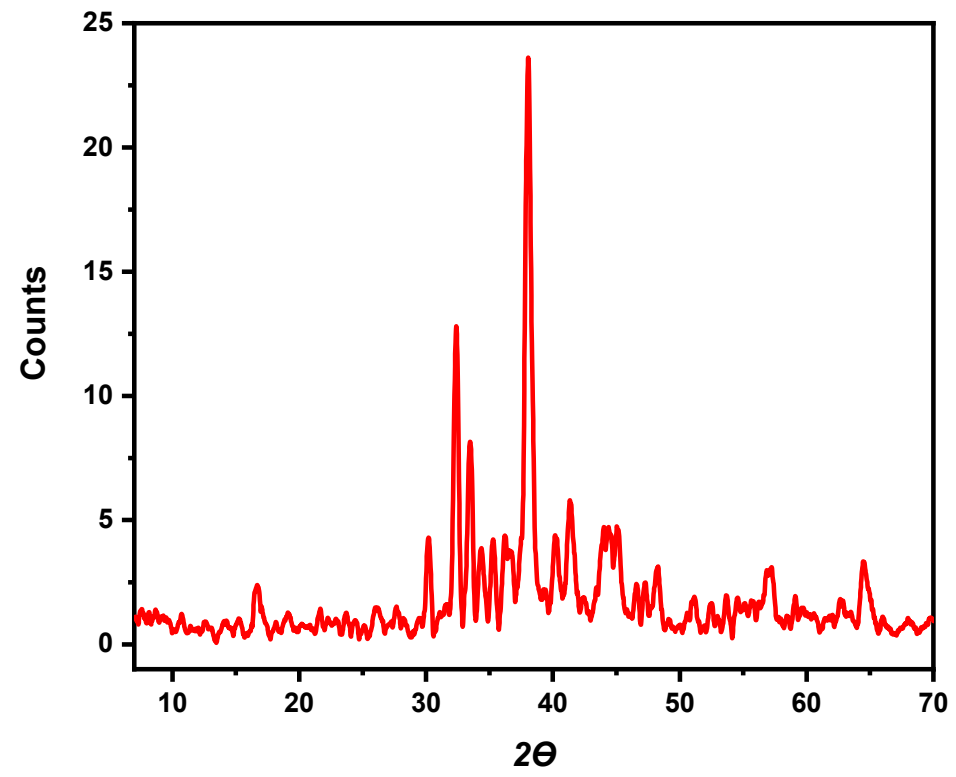

Figure 5. XRD spectrum of AgNPs.

From the observed results, it is clear that GNS-extract is effective in reducing metal salts into its nanoparticles. The presence of bioactive compounds is successful in maintaining stabilization and dispersion to prevent aggregation [46]. The morphology of the shaped AgNPs is studied using a scanning electron microscope. Adsorption of organic moieties from the plant extract is clearly shown by SEM image (Figure 6). The average bio-capped GNSE-are AgNPs circular with a size of $20 \mathrm{~nm}$ or less.

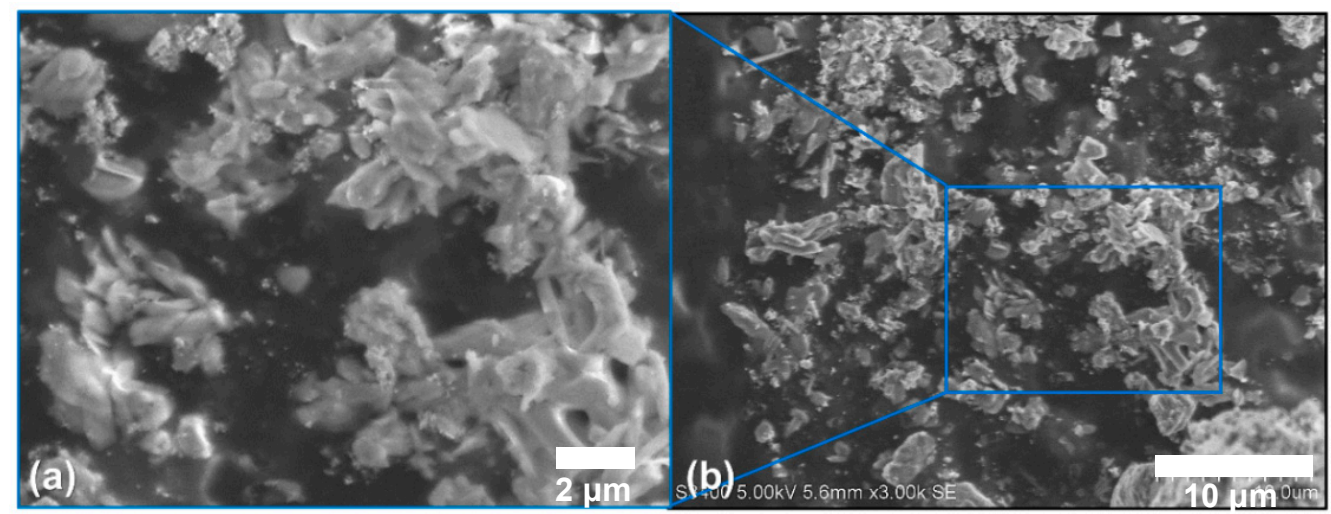

Figure 6. SEM images of AgNPs. (a) at $2 \mu \mathrm{m}$, (b) at $10 \mu \mathrm{m}$. 
The size, scale, form and structure of the synthesized AgNPs have been verified using TEM. TEM pictures are shown, almost spherical Ag particle structures and polydisperse. The histogram of the distribution of the particle size is calculated by TEM in Figure 7. The AgNPs nanoparticles range from $35-40 \mathrm{~nm}$, and the average particle-size length is $\pm 30 \mathrm{~nm}$ in diameter. The selected area electron diffraction pattern (SAED) for AgNPs corresponds to crystallographic planes of FCC pattern of silver.
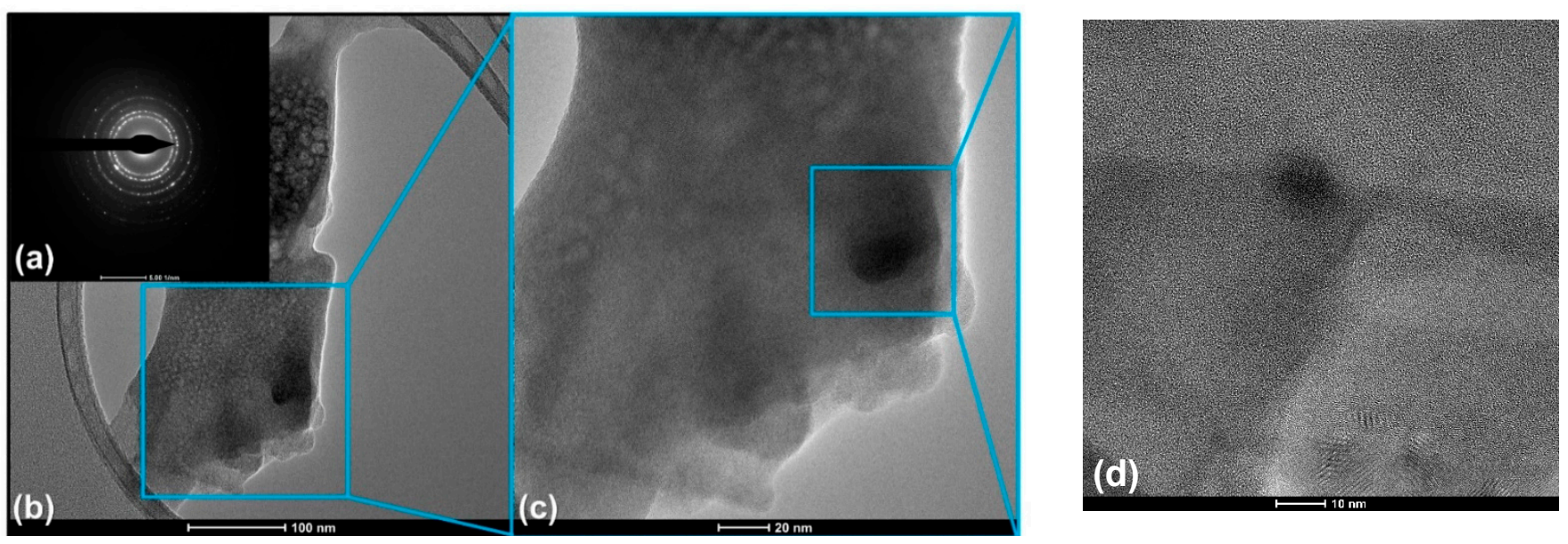

Figure 7. (a) ED pattern, (b-d) HRTEM images of AgNPs.

When it comes small scale observations, the nanoparticles, and their activated surface, from getting charged, causes slight image degradation. The shape of metal nanoparticles is known to significantly vary their optical and elemental properties, which may be determined using the EDX method $[47,48]$. The optical absorption of Ag is clearly shown in the EDAX profile (Figure 8). AgNPs contain $20.05 \%$ of $\mathrm{Ag}$ at $3 \mathrm{keV}$, and in addition to $\mathrm{Cl}, \mathrm{S}$, and Ower, AgNPs also include $\mathrm{Mg}, \mathrm{P}, \mathrm{K}, \mathrm{Ca}, \mathrm{Cu}$, which are captured from the green extract used for synthesis. The percentage of carbon in Fe-PAni fluctuated, which was due to the carbon tape used to attach the samples to the sample holder [49]. FTIR analysis was used to identify the functional groups connected to the AgNPs. The phenolic group in the crude green extract binds to the AgNPs with a high affinity. Other functional groups that AgNPs have connected to include phenol $(-\mathrm{OH})$ at $3442 \mathrm{~cm}^{-1}$, carboxylic acids at $2923 \mathrm{~cm}^{-1}$, and ethers at $1019 \mathrm{~cm}^{-1}$ (Figure 4). After the green production of AgNPs, the supernatant contained less phenol and flavonoid than the green extract (Figure 4). As a result, it was shown that the phytochemical contents may be linked to AgNPs during the green synthesis process. The peaks observed in EDX graph and profile may be due to $\mathrm{K} \alpha_{1}$ and Kedge. When the incident energy of a photon equalled the binding energy of an electron shell in the absorber, such as K, L, or M, etc., a substantial rise was observed for that particular element. This is used to produce a void in the shell while using the least amount of energy possible. This energy was referred to as critical excitation or edge. An electron transfer from another shell filled an initial vacancy in an inner shell produced by an electron or X-ray, leaving a final vacancy in that shell resulting in the characteristic X-ray lines (Figure 5). The energy of lines is equal to the difference between the binding energy of the shells in which the initial and final voids were formed. The excitation of the K, L, M, $\mathrm{N}$ or $\mathrm{O}$ levels lines in an element's X-ray spectra were detected depending on its atomic number. 


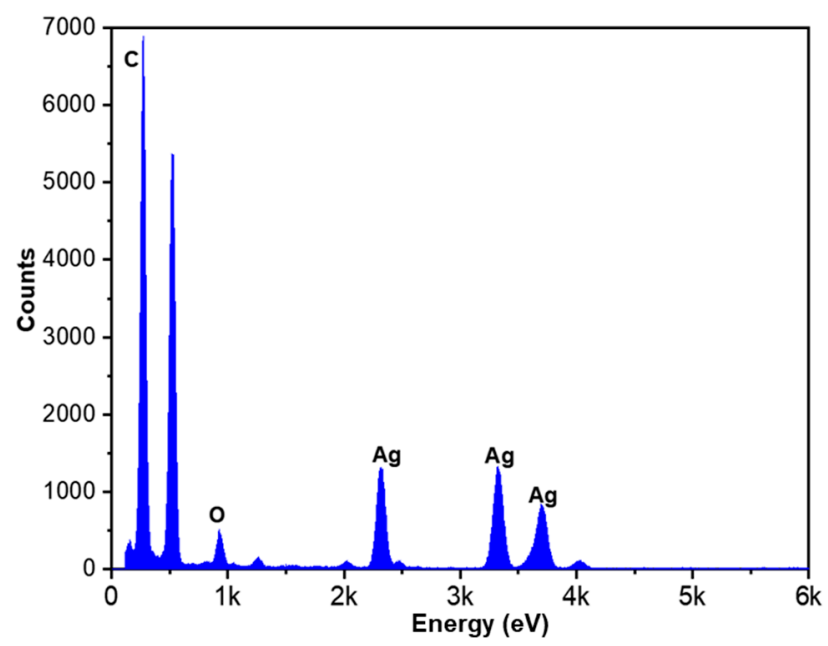

\begin{tabular}{|l|l|l|l|l|l|}
\hline Element & $\begin{array}{l}\text { Weight } \\
(\%)\end{array}$ & Atomic(\%) & $\begin{array}{l}\text { Uncertainty } \\
(\%)\end{array}$ & $\begin{array}{l}\text { Detector } \\
\text { correction }\end{array}$ & $\begin{array}{l}\text { K- } \\
\text { factor }\end{array}$ \\
\hline $\mathrm{C}(\mathrm{K})$ & 18.13 & 29.01 & 0.08 & 0.28 & 3.601 \\
\hline $\mathrm{O}(\mathrm{K})$ & 14.02 & 16.93 & 0.03 & 0.51 & 1.889 \\
\hline $\mathrm{Mg}(\mathrm{K})$ & 1.12 & 0.89 & 00 & 0.88 & 1.05 \\
\hline $\mathrm{P}(\mathrm{K})$ & 1.98 & 1.23 & 0.01 & 0.90 & 1.067 \\
\hline $\mathrm{S}(\mathrm{K})$ & 3.37 & 2.03 & 0.01 & 0.93 & 1.021 \\
\hline $\mathrm{K}(\mathrm{K})$ & 2.05 & 1.01 & 0.01 & 0.97 & 1.086 \\
\hline $\mathrm{Ca}(\mathrm{K})$ & 25.59 & 12.34 & 0.03 & 0.98 & 1.083 \\
\hline $\mathrm{Cu}(\mathrm{K})$ & 13.69 & 4.16 & 0.03 & 0.99 & 1.663 \\
\hline $\mathrm{Ag}(\mathrm{K})$ & 20.05 & 32.4 & 0.01 & 0.90 & 7.089 \\
\hline & 100 & 100 & & & \\
\hline & & & &
\end{tabular}

Figure 8. HRTEM-Energy-dispersive X-ray spectroscopy (EDX) of AgNP; [weight. \%] = the normalised concentration in weight percent of the element; Atomic \%—the atomic weight percent; Uncert \% [wt.\%] = error in the weight percent concentration.

\section{Applications}

\subsection{Corrosion Studies}

\subsubsection{Atomic Absorption Spectroscopy (AAS) Technique}

The AAS was used to evaluate the effects of GNS-AgNPs on aluminium (Al) corrosion in the $1 \mathrm{M}$ hydrochloric acid solution. The pre-weighed $\mathrm{Al}$ was submerged in the $1 \mathrm{M}$ hydrochloric acid $(\mathrm{HCl})$ solution without and with four various concentrations of GNSAgNPs for $10 \mathrm{~h}$ immersion time at $303 \mathrm{~K}$. After the time, the $\mathrm{Al}$ is withdrawn from the $1 \mathrm{M}$ $\mathrm{HCl}$ solution and weight is recorded. The results of AAS are shown in Table 4. The table showed the robust adherence of the GNS-AgNPs on the surface of aluminium in the $1 \mathrm{M}$ $\mathrm{HCl}$. The table shown that the Al weight loss reduced with the introduction of GNS-AgNPs of $0.1,0.2,0.3$, and $0.4 \mathrm{mg} / \mathrm{L}$ in $1 \mathrm{M} \mathrm{HCl}$ soltion. The protection rate enhances with rise in the concentration of GNS-AgNPs is due to an increase in the surface coverage of green nanoparticles over the $\mathrm{Al}$ surface in the $1 \mathrm{M} \mathrm{HCl}$ solution. The adsorption of GNS-AgNPs over the $\mathrm{Al}$ surface generates a barrier for mass and charge transfer, leading to a reduction in the interaction between the $1 \mathrm{M} \mathrm{HCl}$ solution and $\mathrm{Al}$ surface. The existence of GNS-AgNPs film on the $\mathrm{Al}$ surface blocks the $\mathrm{Al}$ surface disintegration. The protection efficiency of GNS-AgNPs on the aluminium surface could be associated with the adsorption of electronrich elements on the empty or partially filled orbitals of $\mathrm{Al}$ in $1 \mathrm{M} \mathrm{HCl}$ solution. As a result, the enhancing stability of newly generated bonds with the green nano particles $[35,38,50]$.

Table 4. Atomic absorption spectroscopy (AAS) technique results.

\begin{tabular}{cccc}
\hline $\begin{array}{c}\text { Concentration } \\
(\mathbf{m g} / \mathrm{L})\end{array}$ & $\begin{array}{c}\text { Optical Density } \\
\text { (O.D) }\end{array}$ & $\begin{array}{c}\text { Weight Loss of } \\
\text { Aluminium in g after } \\
\mathbf{1 0} \text { h Immersion Period }\end{array}$ & $\begin{array}{c}\text { Protection Efficiency } \\
\text { (\%) }\end{array}$ \\
\hline Bare & 0.400 & $30 \times 10^{-3}$ & - \\
0.1 & 0.053 & $1.8 \times 10^{-3}$ & 94.000 \\
0.2 & 0.043 & $1.4 \times 10^{-3}$ & 95.333 \\
0.3 & 0.030 & $8.0 \times 10^{-4}$ & 97.333 \\
0.4 & 0.016 & $1.0 \times 10^{-4}$ & 99.666 \\
\hline
\end{tabular}

\subsubsection{AC Impedance Spectroscopy Technique}

AC impedance spectroscopy explores the kinetics of reactions at the $\mathrm{Al} /$ molar hydrochloric acid solution interface. Figure 9a represents the Nyquist curves obtained from the inhibition of $\mathrm{Al}$ corrosion by using the 1 to $4 \mathrm{mg} / \mathrm{L}$ of GNS-AgNPs. The Nyquist readings are shown the Table 5 . The Nyquist plots (impedance curves) of protected system are 
not different from the unprotected system except in terms of the diameter of the depressed semi-circle.

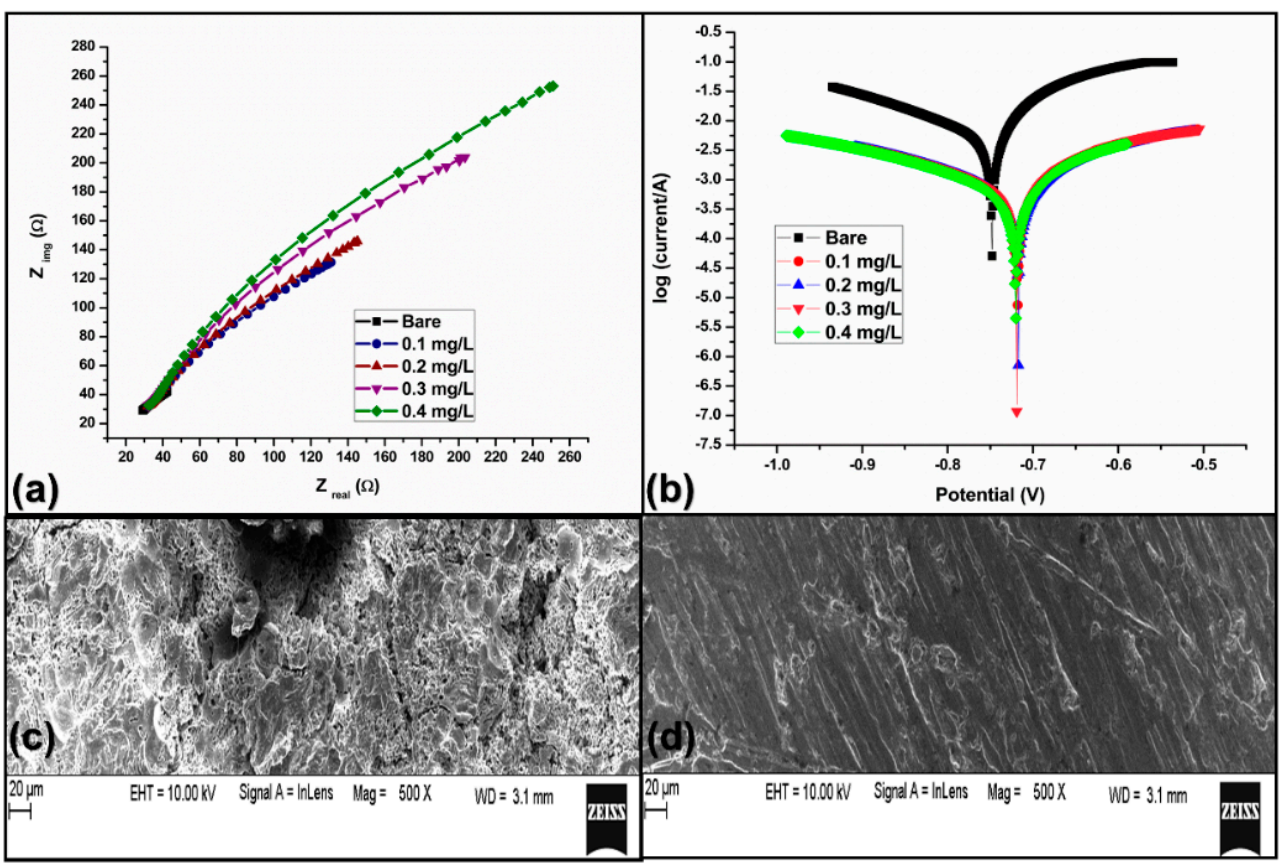

Figure 9. (a) AC impedance spectrum of $\mathrm{Al}$ in $1 \mathrm{M} \mathrm{HCl}$ solution, (b) Tafel plots without and with green nano particles; SEM images without (c) and with inhibitor (d).

Table 5. AC impedance spectroscopy technique results.

\begin{tabular}{ccccc}
\hline $\begin{array}{c}\text { Concentration } \\
(\mathbf{m g} / \mathbf{L})\end{array}$ & $\mathbf{N}$ & $\mathbf{R c t} \boldsymbol{\Omega}$ & $\mathbf{X}^{\mathbf{2}}$ & $\mathbf{\eta z}$ \\
\hline Bare & 0.9174 & 13.35 & 0.00001817 & - \\
0.1 & 0.8863 & 168.4 & 0.00006510 & 92.072 \\
0.2 & 0.8790 & 176.9 & 0.00004471 & 92.453 \\
0.3 & 0.8846 & 181.4 & 0.00009282 & 92.640 \\
0.4 & 0.7953 & 231.7 & 0.00004452 & 94.238 \\
\hline
\end{tabular}

The Nyquits plots in the presence and absence of GNS-AgNPs is not a perfect semicircle due to frequency dispersion. The charge transfer resistance values are and precisely related to the difference of the GNS-AgNPs. The charge transfer resistance values enhance, and the corrosion rate reduces with an increasing concentration of the $\mathrm{Al}, 0.1 \mathrm{mg} / \mathrm{L}, 0.2 \mathrm{mil}$ ligram per liter, $0.3 \mathrm{mg} / \mathrm{L}$ and 0.4 milligram per liter of GNS-AgNPs. The radius of the depressed semicircle enhances with increase in the dosage of GNS-AgNPs is a strong evidence of prevention of dissolution process of $\mathrm{Al}$ in the 1 molar hydrochloric acid solution. The barrier protective layer formed on the Al surface strongly suppresses the disintegration of $\mathrm{Al}$ surface. From this table, it is clear that charge transfer resistance values have a direct relationship with the concentration of GNS-AgNPs [38].

The rise in the charge transfer resistance values with an enhanced concentration of GNS-AgNPs is a clear indication of the anticorrosive behavior of GNS-AgNPs over the Al electrode surface in the $1 \mathrm{M} \mathrm{HCl}$ solution. The best $\mathrm{Al}$ protection was achieved at $0.4 \mathrm{mg} / \mathrm{L}$ of GNS-AgNPs, which showed that significant adsorption at $0.4 \mathrm{mg} / \mathrm{L}$ of GNS-AgNPs on $\mathrm{Al}$ electrodes resulted in high surface coverage area and robust corrosion protection efficiency. Table 6 shows the impedance spectroscopy technique. 
Table 6. Impedance spectroscopy technique results.

\begin{tabular}{cccccc}
\hline $\begin{array}{c}\text { Concentration } \\
(\mathbf{m g} / \mathbf{L})\end{array}$ & $\begin{array}{c}\text { Corrosion } \\
\text { Potential (E } \\
\text { corr) } \mathbf{( m \mathbf { m } )}\end{array}$ & $\begin{array}{c}\text { Anodic Tafel } \\
\text { Slope } \\
\mathbf{( V / d e c )}\end{array}$ & $\begin{array}{c}\text { Cathodic } \\
\text { Tafel Slope } \\
\text { (V/dec) }\end{array}$ & $\begin{array}{c}\text { Corrosion } \\
\text { Current (A) }\end{array}$ & $\begin{array}{c}\text { Protection } \\
\text { Efficiency } \\
\mathbf{( \% )}\end{array}$ \\
\hline Bare & -777 & 0.003 & 6.392 & 0.05570 & - \\
0.1 & -717 & 5.251 & 4.719 & 0.001191 & 89.366 \\
0.2 & -718 & 5.415 & 4.703 & 0.001078 & 90.375 \\
0.3 & -722 & 5.535 & 4.738 & 0.001071 & 90.437 \\
0.4 & -720 & 5.494 & 4.717 & 0.001029 & 90.812 \\
\hline
\end{tabular}

\subsubsection{Tafel Plot (Potentiodynamic Polarization)}

The inhibitor can be classified as cathodic, anodic or mixed type by using the Tafel plot technique. The Tafel plot studies showed that (Figure 9b), by addition of green nanoparticles, they had a significant influence on the aluminum corrosion current density values and low at higher concentration of GNS-AgNPs. As a result of this, there is a remarkable enhancement in the protection efficiency values. The surface area of $\mathrm{Al}$ covered by GNS-AgNPs species enhances with a rise in the amount of GNS-AgNPs, which shows that the aluminum protection is mainly due to the green nanoparticles' adsorption over the $\mathrm{Al}$ surface. The adsorption process suppresses the $\mathrm{Al}$ dissolution process. Further, significant change in the anodic Tafel slope values (from 0.003 to 5.494) compared to cathodic one clearly shows the anodic corrosion inhibition property of the GNS-AgNPs over the $\mathrm{Al}$ surface in the $1 \mathrm{M} \mathrm{HCl}$ solution.

The SEM texture of the aluminium surfaces showing to $1 \mathrm{M} \mathrm{HCl}$ without and with the GNS-AgNPs are observed. The results (Figure 9c) show that the absence of GNS-AgNPs revealed that the aluminium surface was strongly damaged due to corrosive attack by the acid solution. It is seen from Figure $9 \mathrm{~d}$, that a shielding film was formed on the aluminum metal surface in the presence of GNS-AgNPs and the surface became smooth, without any pits, roughness characteristics and cracks over Al surface.

\subsection{Anti-Cancerous Activity on Human Alveolar Cell Lina549, Human Lung Cancer Cells}

The decrease in the efficiency of mitochondrial activity is studied effectively by the toxicity action of ground nutshell extract silver nanoparticles. The large reductions in tetrazolium salts are now well accepted as a healthy tool for measuring cell proliferation. The yellow tetrazolium $\left(\mathrm{C}_{18} \mathrm{H}_{16} \mathrm{BrN}_{5} \mathrm{~S}\right)$ is diminished by metabolically active cells, and delivers a measurable resolve of viable cells through the operation of dehydrogenase enzymes to produce reduced derivatives.

The corresponding intracellular purple formazan can also be solubilized and analyzed by spectrophotometric methods [51,52]. The assay measures the rate of cell proliferation, and vice versa. However, as metabolic processes contribute towards apoptosis or necrosis, cellular uptake declines. The cells being placed on 96 well plates in $100 \mu \mathrm{L}$ of RPMI 1640 and permitted to expand in the subsequent subcellular purple formazan can always be dissolved and studied using spectroscopic methods. The different sampling compositions for 45 to $48 \mathrm{~h}$, the incubation of cells 24 to $28 \mathrm{~h} .20 \mu \mathrm{L} \mathrm{C}{ }_{18} \mathrm{H}_{16} \mathrm{BrN}_{5} \mathrm{~S}$ stock solution is then added to both the plates and incubated for $5 \mathrm{~h}$. The medium is now extracted, and $200 \mu \mathrm{L}$ of DMSO is applied to dissolve the metabolic in each well MTT substance. The plate is rattled at $150 \mathrm{rpm}$ for five minutes and the absorption spectrum at $560 \mathrm{~nm}$. The unprocessed cells (basal) are used to control the viability $(100 \%)$, and the influence is reflected in relation to the regulation as a percent viability $(\log )$, as shown in Figure 10a,b. 

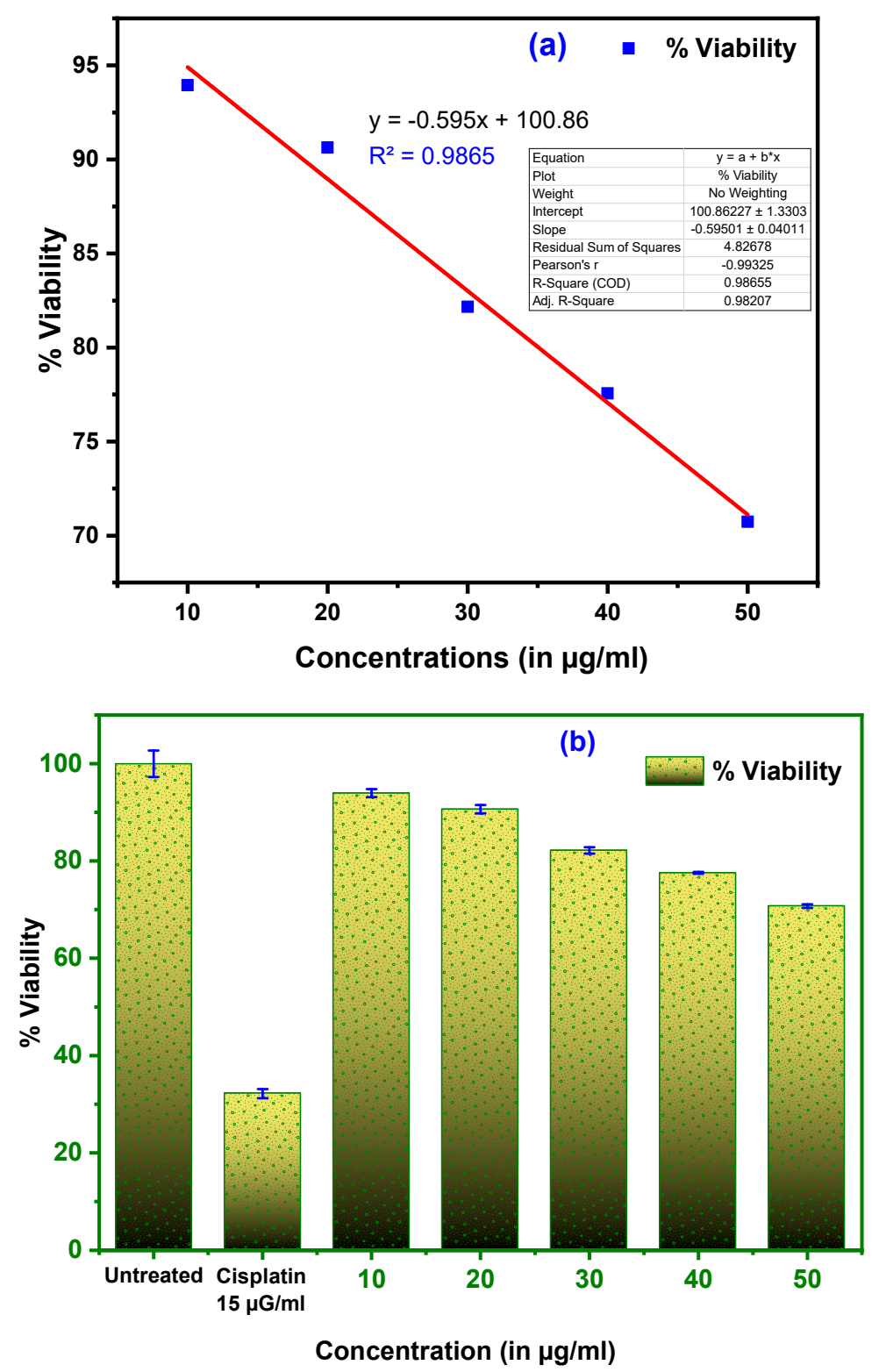

Figure 10. (a) Viability of A549 Cell line Vs. Concentration Sample GNS-AgNPs showing linear corelation (b) With increase in concentration of GNS-AgNPs sample $(\mu \mathrm{g} / \mathrm{mL})$ there is decrease in $\%$ of viability A549 Cell line.

The transformation of yellow tetrazolium salt $\left(\mathrm{C}_{18} \mathrm{H}_{16} \mathrm{BrN}_{5} \mathrm{~S}\right)$ into purple formazan crystals by metabolically active cells gives an accurate confirmation of viable cells. The expected mechanism for cell death is given in the graphical representation (Figure 10) [53-55]. IC-50 value of $85.47 \mu \mathrm{g} / \mathrm{mL}$ for $24 \mathrm{~h}$. The percent inhibition of growth was determined after subtracting the history and the null, and the test drug concentration required to inhibit cell proliferation was created by 50 percent (IC 50) of the dosages curves for the cancer cell $[56,57]$. The probable mechanism for cell apoptosis is explained in Figure 11.

As shown in Figure 11, Apoptosis is the process commonly known as programmed cell death. It is the molecular programming of the cell which leads to its death. In this process the cell is broken down by the protein of itself called Caspases. Thus, for apoptosis to occur, these caspases must be activated. This mechanism of apoptosis, that is, the activation of Caspases, occurs through these three different steps; Step one involves the nitiation, followed by execution and finally phagocytosis. The initiation might be by extrinsic or intrinsic pathways. The process takes place leading to the shrinkage of the cell, either by the intracellular or extracellular process. The synthesized silver nanoparticles act as 
angiogenesis inhibitors [58], which block this angiogenesis process by blocking the nutrient and oxygen sources of a tumour. Further cell starving leads to ell death.

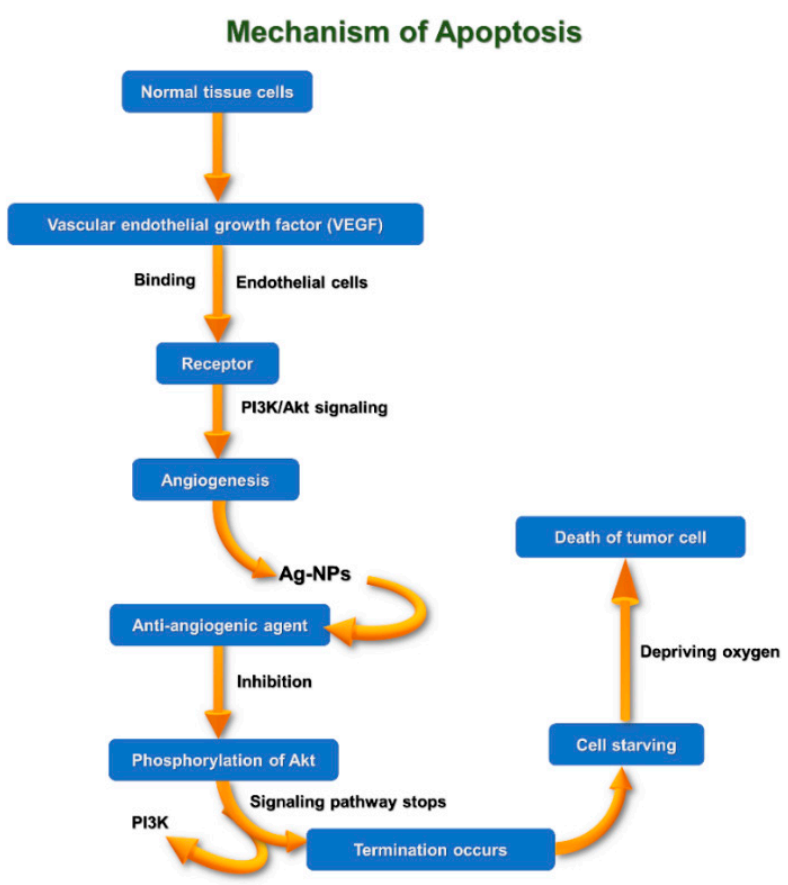

Figure 11. Mechanism of anticancer activity of AgNPs.

\section{Conclusions}

In the present work, we successfully achieved the rapid production of stable and modified sphere shaped (15-20 nm) GNS-AgNPs with high efficiency. Utilizing extracts of groundnut shells as both a reducing agent and a stabilizing agent makes the process cost-effective. The role of Ruthin chemical moieties from the ground nutshell extracts in the reduction process was evaluated, elaborated in detail, and characterized thoroughly. Further, GNS-AgNPs applied as anticorrosion studies found robust anti-corrosion (anodic type) behaviour on $\mathrm{Al}$ in $1 \mathrm{M} \mathrm{HCl}$ system time-dependent mode. The GNS-AgNPs inhibits corrosion, and this property was very helpful in increase the lifetime of aluminium. This property, GNS-AgNPs obtained here, can be useful in various industrial units to mitigate Al corrosion problems. In addition, GNS-AgNPs are biologically active, and it further enhanced phytochemicals and polyphenols etc., present in the bio extract utilized during synthesis. The biological activity realized in the current study, with an importantanticancer activity of GNS AgNPs to effectively control over the A549, human lung Cancer cell viabilities.

Author Contributions: Conceptualization, S.V.G.; methodology, L.V.H.; software, V.B.P.; validation, S.V.G., N.R.B. and T.M.Y.K.; formal analysis, L.V.H., V.B.P., S.V.G., N.R.; investigation, S.V.G.; resources, L.V.H., N.R.; data curation, L.V.H.; writing-original draft preparation, L.V.H., N.R., V.B.P. and S.V.G.; writing-review and editing, N.R.B., T.M.Y.K.; visualization, S.V.G., V.B.P.; supervision, S.V.G.; project administration, S.V.G.; funding acquisition, T.M.Y.K.; I.A.B. All authors have read and agreed to the published version of the manuscript.

Funding: Deanship of Scientific Research at King Khalid University, Saudi Arabia through under Grant No. (R.G.P.1/101/42).

Institutional Review Board Statement: Not applicable.

Informed Consent Statement: Not applicable.

Data Availability Statement: The data presented in this study are available on request from the corresponding author. 
Acknowledgments: The authors extend their appreciation to the Deanship of Scientific Research at King Khalid University for funding this work through research groups program under grant number (R.G.P. 1/101/42), The authors L. V. Hublikar, S. V. Ganachari, N. Raghavendra and N.R. Banapurmath acknowledge the KLE Society Belagavi and KLE Technological University (formerly known as B. V. Bhoomaraddi College of Engineering \& Technology) and Department of Chemistry, KLE's P. C. Jabin Science College, Vidyanagar, Hubballi-580031, Karnataka, INDIA, for supporting research. The authors acknowledge the TEM Facility, funded by a TPF Nano-mission, GoI project at Centre for Nano and Soft Matter Sciences, Bengaluru.

Conflicts of Interest: The authors declare no conflict of interest.

\section{References}

1. Ajayi, E.; Afolayan, A. Green Synthesis, Characterization and Biological Activities of Silver Nanoparticles from Alkalinized Cymbopogon Citratus Stapf. Adv. Nat. Sci. Nanosci. Nanotechnol. 2017, 8. [CrossRef]

2. Riaz, M.; Ismail, M.; Ahmad, B.; Zahid, N.; Jabbour, G.; Khan, M.S.; Mutreja, V.; Sareen, S.; Rafiq, A.; Faheem, M.; et al. Characterizations and Analysis of the Antioxidant, Antimicrobial, and Dye Reduction Ability of Green Synthesized Silver Nanoparticles. Green Process. Synth. 2020, 9, 693-705. [CrossRef]

3. Anantharaman, S.; Rego, R.; Muthakka, M.; Anties, T.; Krishna, H. Andrographis Paniculata-Mediated Synthesis of Silver Nanoparticles: Antimicrobial Properties and Computational Studies. SN Appl. Sci. 2020, 2. [CrossRef]

4. Biswal, S.K.; Behera, M.; Rout, A.S.; Tripathy, A. Green Synthesis of Silver Nanoparticles Using Raw Fruit Extract of Mimusops Elengi and Their Antimicrobial Study. Biointerface Res. Appl. Chem. 2021, 11, 10040-10051. [CrossRef]

5. Ganachari, S.V.; Bhat, R.; Deshpande, R.; Venkataraman, A. Extracellular Biosynthesis of Silver Nanoparticles Using Fungi Penicillium Diversum and Their Antimicrobial Activity Studies. BioNanoScience 2012, 2, 316-321. [CrossRef]

6. Ganachari, S.V.; Deshpande, R.; Bhat, R.; Rao, N.V.S.; Huh, D.S.; Venkataraman, A. Gas Sensing Characteristic of Biofunctionalized Gold Nanoparticles. J. Bionanoscience 2011, 5, 107-112. [CrossRef]

7. Rehman, S.; Farooq, R.; Jermy, R.; Asiri, S.M.; Ravinayagam, V.; Al Jindan, R.; Alsalem, Z.; Shah, M.A.; Reshi, Z.; Sabit, H.; et al. A Wild Fomes Fomentarius for Biomediation of One Pot Synthesis of Titanium Oxide and Silver Nanoparticles for Antibacterial and Anticancer Application. Biomolecules 2020, 10. [CrossRef]

8. Sivaramakrishnan, M.; Jagadeesan Sharavanan, V.; Karaiyagowder Govindarajan, D.; Meganathan, Y.; Devaraj, B.S.; Natesan, S.; Kothandan, R.; Kandaswamy, K. Green Synthesized Silver Nanoparticles Using Aqueous Leaf Extracts of Leucas Aspera Exhibits Antimicrobial and Catalytic Dye Degradation Properties. SN Appl. Sci. 2019, 1. [CrossRef]

9. Akter, M.; Rahman, M.M.; Ullah, A.K.M.A.; Sikder, M.T.; Hosokawa, T.; Saito, T.; Kurasaki, M. Brassica Rapa Var. Japonica Leaf Extract Mediated Green Synthesis of Crystalline Silver Nanoparticles and Evaluation of Their Stability, Cytotoxicity and Antibacterial Activity. J. Inorg. Organomet. Polym. 2018, 28, 1483-1493. [CrossRef]

10. Amaris, Z.N.; Freitas, D.N.; Mac, K.; Gerner, K.T.; Nameth, C.; Wheeler, K.E. Nanoparticle Synthesis, Characterization, and Ecotoxicity: A Research-Based Set of Laboratory Experiments for a General Chemistry Course. J. Chem. Educ. 2017, 94, 1939-1945. [CrossRef]

11. Bhattacharya, K.; Kiliç, G.; Costa, P.M.; Fadeel, B. Cytotoxicity Screening and Cytokine Profiling of Nineteen Nanomaterials Enables Hazard Ranking and Grouping Based on Inflammogenic Potential. Nanotoxicology 2017, 11, 809-826. [CrossRef] [PubMed]

12. Ahmadi, O.; Jafarizadeh-Malmiri, H.; Jodeiri, N. Eco-Friendly Microwave-Enhanced Green Synthesis of Silver Nanoparticles Using Aloe Vera Leaf Extract and Their Physico-Chemical and Antibacterial Studies. Green Process. Synth. 2018, 7, 231-240. [CrossRef]

13. Binod, A.; Ganachari, S.V.; Yaradoddi, J.S.; Tapaskar, R.P.; Banapurmath, N.R.; Shettar, A.S. Biological Synthesis and Characterization of Tri-Metallic Alloy (Au, Ag, Sr) Nanoparticles and Its Sensing Studies. IOP Conf. Ser. Mater. Sci. Eng. 2018, $376,012054$. [CrossRef]

14. Ganachari, S.V.; Yaradoddi, J.S.; Somappa, S.B.; Mogre, P.; Tapaskar, R.P.; Salimath, B.; Venkataraman, A.; Viswanath, V.J. Green nanotechnology for biomedical, food, and agricultural applications. In Handbook of Ecomaterials; Springer International Publishing: Berlin/Heidelberg, Germany, 2019; Volume 4, pp. 2681-2698, ISBN 9783319682556.

15. Ganachari, S.V.; Hublikar, L.; Yaradoddi, J.S.; Math, S.S. Metal oxide nanomaterials for environmental applications. In Handbook of Ecomaterials; Springer International Publishing: Berlin/Heidelberg, Germany, 2019; Volume 4, pp. 2357-2368, ISBN 9783319682556.

16. Ganachari, S.V. Polymers for energy applications. In Handbook of Ecomaterials; Springer International Publishing: Berlin/Heidelberg, Germany, 2019; Volume 4, pp. 3011-3027, ISBN 9783319682556.

17. Ganachari, S.V.; Banapurmath, N.R.; Salimath, B.; Yaradoddi, J.S.; Shettar, A.S.; Hunashyal, A.M.; Venkataraman, A.; Patil, P.; Shoba, H.; Hiremath, G.B. Synthesis techniques for preparation of nanomaterials. In Handbook of Ecomaterials; Springer International Publishing: Berlin/Heidelberg, Germany, 2019; Volume 1, pp. 83-103, ISBN 9783319682556.

18. Abid, C.K.V.Z.; Jain, S.; Jackeray, R.; Chattopadhyay, S.; Singh, H. Formulation and Characterization of Antimicrobial Quaternary Ammonium Dendrimer in Poly(Methyl Methcarylate) Bone Cement. J. Biomed. Mater. Res. Part. B Appl. Biomater. 2017, 105, 521-530. [CrossRef] [PubMed] 
19. Alam, T.; Khan, R.A.A.; Ali, A.; Sher, H.; Ullah, Z.; Ali, M. Biogenic Synthesis of Iron Oxide Nanoparticles via Skimmia Laureola and Their Antibacterial Efficacy against Bacterial Wilt Pathogen Ralstonia Solanacearum. Mater. Sci. Eng. C 2019, 98, 101-108. [CrossRef]

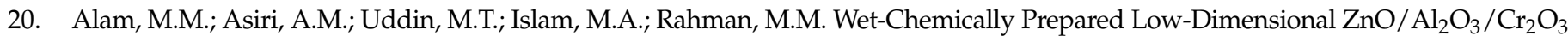
Nanoparticles for Xanthine Sensor Development Using an Electrochemical Method. RSC Adv. 2018, 8, 12562-12572. [CrossRef]

21. Fang, L.; Feng, J.J.; Shi, X.; Si, T.; Song, Y.; Jia, H.; Li, Y.; Li, H.-W.; Zhang, Q. Turning Bulk Materials into 0D, 1D and 2D Metallic Nanomaterials by Selective Aqueous Corrosion. Chem. Commun. 2019, 55, 10476-10479. [CrossRef]

22. Cai, J.; Li, Y.; Liu, C.; Wang, X. Green and Controllable Synthesis of Au-Ag Bimetal Nanoparticles by Xylan for Surface-Enhanced Raman Scattering. ACS Sustain. Chem. Eng. 2019, 7, 15154-15162. [CrossRef]

23. Idrees, M.; Batool, S.; Kalsoom, T.; Raina, S.; Sharif, H.M.A.; Yasmeen, S. Biosynthesis of Silver Nanoparticles Using Sida Acuta Extract for Antimicrobial Actions and Corrosion Inhibition Potential. Environ. Technol. 2019, 40, 1071-1078. [CrossRef]

24. Gogoi, B.; Kumar, R.; Upadhyay, J.; Borah, D. Facile Biogenic Synthesis of Silver Nanoparticles (AgNPs) by Citrus Grandis (L.) Osbeck Fruit Extract with Excellent Antimicrobial Potential against Plant Pathogens. SN Appl. Sci. 2020, 2. [CrossRef]

25. Javed, B.; Nadhman, A.; Razzaq, A.; Mashwani, Z.-U.-R. One-Pot Phytosynthesis of Nano-Silver from Mentha Longifolia L.: Their Characterization and Evaluation of Photodynamic Potential. Mater. Res. Express 2020, 7. [CrossRef]

26. Javed, B.; Nadhman, A.; Mashwani, Z.-U.-R. Optimization, Characterization and Antimicrobial Activity of Silver Nanoparticles against Plant Bacterial Pathogens Phyto-Synthesized by Mentha Longifolia. Mater. Res. Express 2020, 7. [CrossRef]

27. Kumar, A.S.; Madhu, G.; John, E.; Kuttinarayanan, S.V.; Nair, S.K. Optical and Antimicrobial Properties of Silver Nanoparticles Synthesized via Green Route Using Honey. Green Process. Synth. 2020, 9, 268-274. [CrossRef]

28. Arya, G.; Mankamna Kumari, R.; Sharma, N.; Chatterjee, S.; Gupta, N.; Kumar, A.; Nimesh, S. Evaluation of Antibiofilm and Catalytic Activity of Biogenic Silver Nanoparticles Synthesized from Acacia Nilotica Leaf Extract. Adv. Nat. Sci. Nanosci. Nanotechnol. 2018, 9. [CrossRef]

29. Ananda Murthy, H.C.; Desalegn Zeleke, T.; Ravikumar, C.R.; Anil Kumar, M.R.; Nagaswarupa, H.P. Electrochemical Properties of Biogenic Silver Nanoparticles Synthesized Using Hagenia Abyssinica (Brace) JF. Gmel. Medicinal Plant Leaf Extract. Mater. Res. Express 2020, 7. [CrossRef]

30. Anandan, M.; Poorani, G.; Boomi, P.; Varunkumar, K.; Anand, K.; Chuturgoon, A.A.; Saravanan, M.; Gurumallesh Prabu, H. Green Synthesis of Anisotropic Silver Nanoparticles from the Aqueous Leaf Extract of Dodonaea Viscosa with Their Antibacterial and Anticancer Activities. Process. Biochem. 2019, 80, 80-88. [CrossRef]

31. Lakshmanan, G.; Sathiyaseelan, A.; Kalaichelvan, P.T.; Murugesan, K. Plant-Mediated Synthesis of Silver Nanoparticles Using Fruit Extract of Cleome Viscosa L.: Assessment of Their Antibacterial and Anticancer Activity. Karbala Int. J. Mod. Sci. 2018, 4, 61-68. [CrossRef]

32. Ganguly, B.N.; Maity, B.; Maity, T.K.; Manna, J.; Roy, M.; Mukherjee, M.; Debnath, S.; Saha, P.; Shilpa, N.; Rana, R.K. L-CysteineConjugated Ruthenium Hydrous Oxide Nanomaterials with Anticancer Active Application. Langmuir 2018, 34, $1447-1456$. [CrossRef]

33. Fetouh, H.A.; Hefnawy, A.; Attia, A.M.; Ali, E. Facile and Low-Cost Green Synthesis of Eco-Friendly Chitosan-Silver Nanocomposite as Novel and Promising Corrosion Inhibitor for Mild Steel in Chilled Water Circuits. J. Mol. Liq. 2020, 319. [CrossRef]

34. Manjumeena, R.; Venkatesan, R.; Duraibabu, D.; Sudha, J.; Rajendran, N.; Kalaichelvan, P.T. Green Nanosilver as Reinforcing Eco-Friendly Additive to Epoxy Coating for Augmented Anticorrosive and Antimicrobial Behavior. Silicon 2016, 8, 277-298. [CrossRef]

35. Raghavendra, N.; Ishwara Bhat, J. Inhibition of Al Corrosion in 0.5M HCl Solution by Areca Flower Extract. J. King Saud Univ.-Eng. Sci. 2019, 31, 202-208. [CrossRef]

36. Balamurugan, C.; Jeong, Y.J.; Lee, D.W. Enhanced $\mathrm{H}_{2} \mathrm{~S}$ Sensing Performance of a P-Type Semiconducting PdO-NiO Nanoscale Heteromixture. Appl. Surf. Sci. 2017, 420, 638-650. [CrossRef]

37. Prochowicz, D.; Kornowicz, A.; Lewiński, J. Interactions of Native Cyclodextrins with Metal Ions and Inorganic Nanoparticles: Fertile Landscape for Chemistry and Materials Science. Chem. Rev. 2017, 117, 13461-13501. [CrossRef] [PubMed]

38. Raghavendra, N. Green Compounds to Attenuate Aluminum Corrosion in $\mathrm{HCl}$ Activation: A Necessity Review. Chem. Afr. 2020, 3, 21-34. [CrossRef]

39. Arasu, M.V.; Arokiyaraj, S.; Viayaraghavan, P.; Kumar, T.S.J.; Duraipandiyan, V.; Al-Dhabi, N.A.; Kaviyarasu, K. One Step Green Synthesis of Larvicidal, and Azo Dye Degrading Antibacterial Nanoparticles by Response Surface Methodology. J. Photochem. Photobiol. B Biol. 2019, 190, 154-162. [CrossRef] [PubMed]

40. Alfuraydi, A.A.; Devanesan, S.; Al-Ansari, M.; AlSalhi, M.S.; Ranjitsingh, A.J. Eco-Friendly Green Synthesis of Silver Nanoparticles from the Sesame Oil Cake and Its Potential Anticancer and Antimicrobial Activities. J. Photochem. Photobiol. B Biol. 2019, 192, 83-89. [CrossRef]

41. Hembram, K.C.; Kumar, R.; Kandha, L.; Parhi, P.K.; Kundu, C.N.; Bindhani, B.K. Therapeutic Prospective of Plant-Induced Silver Nanoparticles: Application as Antimicrobial and Anticancer Agent. Artif. Cells Nanomed. Biotechnol. 2018, 46, S38-S51. [CrossRef] [PubMed]

42. Hamelian, M.; Zangeneh, M.M.; Amisama, A.; Varmira, K.; Veisi, H. Green Synthesis of Silver Nanoparticles Using Thymus Kotschyanus Extract and Evaluation of Their Antioxidant, Antibacterial and Cytotoxic Effects. Appl. Organomet. Chem. 2018, 32, e4458. [CrossRef] 
43. Erci, F.; Cakir-Koc, R.; Isildak, I. Green Synthesis of Silver Nanoparticles Using Thymbra Spicata L. Var. Spicata (Zahter) Aqueous Leaf Extract and Evaluation of Their Morphology-Dependent Antibacterial and Cytotoxic Activity. Artif. Cells Nanomed. Biotechnol. 2018, 46, 150-158. [CrossRef]

44. Ahmad, S.; Munir, S.; Zeb, N.; Ullah, A.; Khan, B.; Ali, J.; Bilal, M.; Omer, M.; Alamzeb, M.; Salman, S.M.; et al. Green Nanotechnology: A Review on Green Synthesis of Silver Nanoparticles-An Ecofriendly Approach. Int. J. Nanomed. 2019, 14, 5087-5107. [CrossRef]

45. Al-Dhabi, N.A.; Mohammed Ghilan, A.-K.; Arasu, M.V. Characterization of Silver Nanomaterials Derived from Marine Streptomyces Sp. Al-Dhabi-87 and Its in Vitro Application against Multidrug Resistant and Extended-Spectrum Beta-Lactamase Clinical Pathogens. Nanomaterials 2018, 8. [CrossRef]

46. Wijesena, R.N.; Tissera, N.D.; Abeyratne, C.; Bangamuwa, O.M.; Ludowyke, N.; Dahanayake, D.; Gunasekara, S.; de Silva, N.; de Silva, R.M.; de Silva, K.M.N. In-Situ Formation of Supramolecular Aggregates between Chitin Nanofibers and Silver Nanoparticles. Carbohydr. Polym. 2017, 173, 295-304. [CrossRef]

47. Xu, H.; Käll, M. Surface-Plasmon-Enhanced Optical Forces in Silver Nanoaggregates. Phys. Rev. Lett. 2002, 89, 246802. [CrossRef]

48. Suman, T.Y.; Elumalai, D.; Kaleena, P.K.; Rajasree, S.R.R. GC-MS Analysis of Bioactive Components and Synthesis of Silver Nanoparticle Using Ammannia Baccifera Aerial Extract and Its Larvicidal Activity against Malaria and Filariasis Vectors. Ind. Crop. Prod. 2013, 47, 239-245. [CrossRef]

49. Govindarajan, M.; Benelli, G. One-Pot Green Synthesis of Silver Nanocrystals Using Hymenodictyon Orixense: A Cheap and Effective Tool against Malaria, Chikungunya and Japanese Encephalitis Mosquito Vectors? RSC Adv. 2016, 6, 59021-59029. [CrossRef]

50. Raghavendra, N.; Bhat, J.I. Red Arecanut Seed Extract as a Sustainable Corrosion Inhibitor for Aluminum Submerged in Acidic Corrodent: An Experimental Approach Towards Zero Environmental Impact. Period. Polytech. Chem. Eng. 2018, 62, 351-358. [CrossRef]

51. Khatami, M.; Sharifi, I.; Nobre, M.A.L.; Zafarnia, N.; Aflatoonian, M.R. Waste-Grass-Mediated Green Synthesis of Silver Nanoparticles and Evaluation of Their Anticancer, Antifungal and Antibacterial Activity. Green Chem. Lett. Rev. 2018, 11, 125-134. [CrossRef]

52. Sarkar, S.; Kotteeswaran, V. Green Synthesis of Silver Nanoparticles from Aqueous Leaf Extract of Pomegranate (Punica Granatum) and Their Anticancer Activity on Human Cervical Cancer Cells. Adv. Nat. Sci. Nanosci. Nanotechnol. 2018, 9. [CrossRef]

53. Sanaeimehr, Z.; Javadi, I.; Namvar, F. Antiangiogenic and Antiapoptotic Effects of Green-Synthesized Zinc Oxide Nanoparticles Using Sargassum Muticum Algae Extraction. Cancer Nanotechnol. 2018, 9, 3. [CrossRef] [PubMed]

54. Özkan, A.; Atar, N.; Yola, M.L. Enhanced Surface Plasmon Resonance (SPR) Signals Based on Immobilization of Core-Shell Nanoparticles Incorporated Boron Nitride Nanosheets: Development of Molecularly Imprinted SPR Nanosensor for Anticancer Drug, Etoposide. Biosens. Bioelectron. 2019, 130, 293-298. [CrossRef]

55. Shandilya, R.; Bhargava, A.; Bunkar, N.; Tiwari, R.; Goryacheva, I.Y.; Mishra, P.K. Nanobiosensors: Point-of-Care Approaches for Cancer Diagnostics. Biosens. Bioelectron. 2019, 130, 147-165. [CrossRef]

56. Vijayan, R.; Joseph, S.; Mathew, B. Indigofera Tinctoria Leaf Extract Mediated Green Synthesis of Silver and Gold Nanoparticles and Assessment of Their Anticancer, Antimicrobial, Antioxidant and Catalytic Properties. Artif. Cells Nanomed. Biotechnol. 2018, 46, 861-871. [CrossRef] [PubMed]

57. Palem, R.R.; Ganesh, S.D.; Kronekova, Z.; Sláviková, M.; Saha, N.; Saha, P. Green Synthesis of Silver Nanoparticles and Biopolymer Nanocomposites: A Comparative Study on Physico-Chemical, Antimicrobial and Anticancer Activity. Bull. Mater. Sci. 2018, 41, 55. [CrossRef]

58. Soenen, S.J.H.; Illyes, E.; Vercauteren, D.; Braeckmans, K.; Majer, Z.; de Smedt, S.C.; de Cuyper, M. The Role of Nanoparticle Concentration-Dependent Induction of Cellular Stress in the Internalization of Non-Toxic Cationic Magnetoliposomes. Biomaterials 2009, 30, 6803-6813. [CrossRef] [PubMed] 